\title{
Empirical Law and Economics Scholarship in China: Methodologies and Challenges
}

\author{
Ruoying CHEN* \\ Law School, Peking University
}

\begin{abstract}
Providing a survey of empirical law and economics scholarship in China, this paper shows the binary categories of quantitative versus qualitative studies are inadequate. Instead, two paths for future research in empirical law and economics in China are identified, namely studies based upon individual cases and studies that apply social scientific tools to analyze data, such as statistical and experimental tools. This paper also emphasizes the unique value of empirical law and economics for Chinese scholars in the increasingly globalized academic world.
\end{abstract}

Keywords: law and economics, empirical study, China, Chinese legal scholarship

\section{INTRODUCTION}

Among interdisciplinary work between law and the social sciences, that between law and economics is perhaps the most exciting. ${ }^{1}$ Since its introduction by Chinese scholars in the early $1980 \mathrm{~s},{ }^{2}$ the basic concepts and analytical framework of law and economics have become familiar in China. Substantial Chinese scholarship on the theoretical aspects of law and economics has emerged, including those highlighting China-specific contexts. ${ }^{3}$ More recently, there has been a more comprehensive and wide-ranging introduction of law and economics scholarship into China through translations and commentaries. ${ }^{4}$ Institutionally, rapid developments have occurred: many universities have established dedicated research

* Associate Professor, Peking University Law School \& Visiting Associate Professor, University of Chicago Law School (2016-17). Correspondence to Ruoying Chen, No. 5 Yi He Yuan Road, Peking University Law School, Chen Ming BLDG, 100871, Beijing, China. E-mail address: ruoyingc@pku.edu.cn. For valuable discussions, see an earlier Chinese draft of this paper, "Empirical Legal Study in China: Paths and Challenges," which was published in the Journal of Law and Social Sciences (“中国法律经济学的实证研究：路径与挑战” , 法律和社会科学 , 2011). I am grateful to Ai Jiahui, Bai Jianjun, Richard Epstein, Hou Meng, Saul Levmor, Li Ruijian, Liao Zhimin, Liu Sida, Thomas Mile, Wang Qinghua, and Xue Zhaofeng. Thanks to Ji Weidong, Xu Chenggang, and anonymous referees for valuable suggestions on the English draft, which is substantially updated based on the earlier version in Chinese. I am grateful to Apple Clancy and Matthias Vanhullebusch for very helpful language editing. For the purposes of this paper, references to law and economics scholarship outside of China are limited to those in the US, unless otherwise specifically addressed, given the dominance of scholars there in this particular field.

1. Landes \& Posner (1993).

2. For early introductions, see Zhang (1995); Zhou (1998); Qian (2003); Shi (2014).

3. See e.g. Xi (2013); Shi, Jinchuan, ed.

4. Some examples are Feng (2006); Shi, supra note 2; Luo (2006). 
institutes focusing on law and economics. ${ }^{5}$ A key milestone was the establishment of the Ronald Coase Institute of Law and Economics at Shanghai Jiao Tong University in 2015, which is currently directed by economists Xu Chenggang and Wang Ning, a co-author with and lifelong collaborator of Ronald Coase. Chinese scholars have also published a number of textbooks on law and economics, ${ }^{6}$ and various law schools have been offering courses on law and economics. Empirical law and economics scholarship has also emerged ${ }^{7}$ and the work by Professor Zhu Suli had a theoretical breakthrough. ${ }^{8}$ In particular, the efforts of Professor Zhu and his followers have largely promoted interdisciplinary legal study through the establishment and editing of the Journal of Law and Social Sciences, including law and economics. ${ }^{9}$ Moreover, the interdisciplinary approach has been officially endorsed by the top social sciences journal: this journal has been hosting conferences focusing on interdisciplinary studies for four years now. ${ }^{10}$

This paper is neither the first commenting on empirical legal studies in China ${ }^{11}$ nor does it aim at an exhaustive review of all major and current works by Chinese scholars on law and economics. However, it is far from enough to simply point out that there is room for development in this area for Chinese scholars. Existing commentaries have touched on quantitative law and economics study, ${ }^{12}$ but the emphasis on the distinction between "qualitative" and "quantitative" studies fails to fully illustrate methodological differences in approaches to empirical studies. Hence, more careful study is needed to fully understand challenges and opportunities present in the area of empirical law and economics study. Instead of focusing on individual scholarship, the review here will focus on different methodologies within empirical law and economics, thereby helping to enhance the quality of future studies and commentaries in this area. Particularly, in response to the existing emphasis on utilizing local resources for research, I hope to identify the unique value of empirical study with respect to law and economics in China, as well as outside of China.

The rest of the paper is organized as follows: Section 1 identifies two basic methods for empirical law and economics research. The first empirical method is quantitative, based on historical data or data generated by experiments to either identify (or disprove) causal relations. The second empirical method is case-study, examining the institutional details and background of individual cases. This method does not necessarily involve a substantial amount of data or data analysis. In employing such a method, even when data are used, analysis is far from quantitative. Section 2 points out particular challenges to the quantitative study of law and economics in China. Section 3 points out that empirical law and economics

5. Many top universities in China have created research institutes dedicated to the teaching and research of law and economics, e.g. China University of Political Science and Law, Peking University, Renmin University, Shandong University, Shanghai Jiao Tong University, Sun Yat-Sen University, and Zhejiang University.

6. Shi, supra note 2 .

7. Su (2006a); Zhou (2006); Zhou (2007).

8. Su (2006b); Zhang \& Deng (2003); Ding (2005); Ai (2007).

9. The second special issue of this journal was on law and economics, consisting mostly of empirical work.

10. The conference is entitled the China Interdisciplinary Study Forum (“中国社会科学跨学科论坛”) and the most recent one was held in September 2016; see http://www.cssn.cn/zx/201609/t20160925_3213744.shtml (accessed 29 July 2017).

11. See e.g. Wang \& Lai (2008). For the purposes of this paper, unless otherwise mentioned, I did not include law and economics scholarship conducted by scholars in Taiwan, Hong Kong, or Macau. For a general account of law and economic scholarship in Taiwan, see Huang (2014).

12. See e.g. Wang \& Hou (2007). 
scholarship in China can help to better integrate Chinese legal scholarship into global discourses, and claims that Chinese scholars could make unique contributions to legal scholarship by applying these methods.

\section{TWO METHODS OF EMPIRICAL LAW AND ECONOMICS: QUANTITATIVE METHOD AND CASE-STUDY}

Since its inception, the field of law and economics has been strongly empirical, challenging the highly abstract approach to theoretical inquiries into law and economics. ${ }^{13}$ Once could even claim no law and economics scholar in the US is anti-empirical, although fundamentally different methods exist. The first step consists in introducing these methods.

In China, Professor Bai Jianjun first comprehensively introduced and employed these empirical methods. He defined empirical legal study to be a method "of empirical and quantitative study conducted according to a designated procedure." He identified three basic factors fundamental to empirical methods: designated procedures, empirical data/ information, and quantitative analysis. ${ }^{14}$ Such an understanding fits well with general regression studies of mass data, which have long existed in the law and economics scholarship. ${ }^{15}$ In addition, another type of empirical method should be included: case-study, which was pioneered by scholars like Ronald Coase and has been developing ever since. According to this method, scholars conduct research on one or more individual cases, investigating the details of these cases without having to code the information. When using this method, scholars usually do not conduct quantitative analysis of the information included in cases, although this method shares the same goal as quantitative study in confirming or challenging an existing hypothesis. With regard to information collection and analysis, the two methods diverge. With quantitative study, a newly emerging and increasing popular tool consists of data collection through tailored experiments or analysis of existing data generated in past experiments. This tool has given rise to the entirely new field of behavioural law and economics. As it is data-based, and analysis consists of using statistical methods such as regression, it belongs to the category of quantitative methods. ${ }^{16}$

In contradistinction to widespread misconceptions, the methods of quantitative study and case-study are not at odds, but develop in parallel, providing different perspectives in law and economics scholarship. With the above outline in place, it is now possible to more closely examine each of these methods and their development in China.

13. Ronald Coase famously said that what is studied is a system which lives in the minds of economists but not on Earth; see Coase (1994b), p. 5. Richard Posner also criticized current literature and promoted research focusing on specific problems and applying multidisciplinary tools; see Posner (1993a), p. 214.

14. Bai (2000); Bai (2008). For a more updated review of empirical legal studies in China, see Cheng (2015), pp. 60-78.

15. There exists a split over a narrow versus more comprehensive understanding of "empirical legal study" in the US. Professor Lee Epstein claims it includes a wide range of research that involves legal data from the real world, which does not necessarily apply statistical or other quantitative tools, and where the scope and amount of data covered does not have to be substantial. The narrower view of empirical legal study, however, requires that it must employ a professional research method that applies statistics and other quantitative methods to draw inferences from a substantial data set; see Epstein \& King (2002).

16. Sunstein (2000). With respect to the two different approaches to conducting behavioural law and economics research-namely the psychologic approach and the approach of neoclassics economics—see the dialogue between two law and economics scholars: Epstein \& Bar-Gill (2007). 
The first method in empirical law and economics is quantitative study. ${ }^{17}$ It consists of four steps: the presentation of data, formulation of a hypothesis to test, quantitative analysis, and application. ${ }^{18}$ This method tests an existing hypothesis by analyzing a substantial amount of data and stylized facts. Quantitative analytical tools and models-especially regression models - connect data to hypotheses. In collecting and processing data, rules and norms that have traditionally been employed in statistical analysis should be followed. When the data are representative and the results are statistically significant, results from the application of these methods can shed light on things we do not know about the real world, providing evidence to use in assessing existing legal institutions and formulating plans to improve intuitions.

In the US, the birthplace of law and economics, such data-driven methods of empirical law and economics have long been a critical part of the scholarship. George Stigler, who won the Nobel Prize in economics, is one of the early heroes in this field, whose scholarship has had a profound and lasting effect. ${ }^{19}$ Gary Becker is another, having applied such methods to provide unique insights into crimes and punishment, ${ }^{20}$ who has become the cornerstone of modern legal scholarship on criminal and criminal procedural law. All elite law schools in the US have permanent faculty specialized in empirical law and economics, and almost all of them have $\mathrm{PhD}$ degrees in economics or political science, ${ }^{21}$ which are themselves highly empirical disciplines. The newly elected Dean of the University of Chicago Law School, Tom Miles, is one of the leading law and economics empiricists in the US. The prominent position of this research is demonstrated by the fact that almost all the recent papers published in Journal of Legal Studies, created by Richard Posner, come from the field of empirical law and economics, exploring large data sets. Additionally, Richard Posner himself has been focusing on the empirical study of judicial behaviour for the past few years, and has been teaching a yearlong workshop on judicial behaviours in the University of Chicago Law School.

The scientific nature and stringent procedural requirements have added new weight to the persuasiveness and attractiveness of empirical methods in legal studies. However, to be valuable to legal scholarship and policy-making, the application of this method should apply not only standard criteria of social sciences research, but also unique measurements from legal scholarship. So far, this method has been applied to legal issues in China, such as judicial reform, criminal law, ${ }^{22}$ and securities regulations. ${ }^{23}$ With respect to the formulation and application of theoretical frameworks and hypotheses, these scholars often started with

17. Landes (2003).

18. Hong (2007).

19. For example, both Ronald Coase and Harold Demsetz have praised the utilization of data and quantitative methods for the sake of analysis and argumentation; see Wright \& Stigler (2006); Coase (1994a); Demsetz (1993). Stigler's contributions to law and economics are not limited to the application of quantitative methodologies to analyze legal issues. His work on certain specific area of legal issues, such as antitrust law, has opened up entirely new directions for the legal study of regulations; see Stigler \& Friedland (1962), pp. 1-16. Subsequent work introduced rational choice into the analysis of the behaviour of regulatory officials, which paved the way for public choice theories and is hugely influential in applying law and economics to non-market transaction issues; see Stigler (1971), pp. 3-21.

20. Becker (1968), pp. 169-217.

21. Such as Mitchell Polinsky, Steven Shavell, and William Landes.

22. Bai (2001); Bai (2003).

23. Professor XiChao (习超) of China University of Hong Kong and Professor Xu Wenming (徐文明) of China University of Political Science and Law. See the relevant papers on their respective SSRN pages: https://papers.ssrn. 
well-established frameworks and hypotheses from the US, with modifications to reflect the reality in China and to make them more relevant to China. ${ }^{24}$ Such attempts respond effectively to the claims by Milton Friedman that empirical study in economics should constantly update existing hypotheses and theoretical frameworks. ${ }^{25}$

Quantitative study has a unique value, confining academic discussions and critiques to calm and reasonable environments. On the one hand, the data and stylized facts are highly abstracted from reality, with much of the emotion-provoking details completely stripped away, thereby helping to avoid highly charged emotional confrontations. Meanwhile, most tools and measurements are universally accepted and used by the relevant scholars, providing a consistent set of criteria in assessing quality and defects in research. In China, such a function is particularly valuable: many scholars working in law and economics, and the broader fields of law and social sciences, have established a culture of open and rigorous critique and discussion, somewhat rare in China. ${ }^{26}$ Such fundamental change would surely help the establishment and development of an academic community united around diversified research methods-instead of particular subject areas-which is not only healthy, but also necessary in today's world.

The case-study, a second type of empirical method used in law and economics, does not focus on whether the target of analysis is representative of a broader population, and this method does not require the coding of information or statistical analyses of the information collected. Such study could be based exclusively on a case resulting in a controversial judicial decision, or a series of examples identified through methodologies similar to field study and investigations. ${ }^{27} \mathrm{Mr}$ Coase has demonstrated the value of this method in numerous works. ${ }^{28}$ Many have followed him, such as Robert Ellickson in his seminal piece "Order without Law: How Neighbors Resolve Disputes"29 and Lisa Bernstein in her study of rules and dispute resolution in the New York diamond industry. ${ }^{30}$ In such scholarship, the choices of individual cases and their descriptions are diverse and demonstrate differences in the understanding, application, and innovation of law and economics theories. The research in such work is not subject to any stringent methodological requirements. The openness and particularity of the scope of study and methodologies applied best exemplify the revolutionary nature and attractiveness of case-study research in law and economics.

Chinese economists began employing this method before legal scholars. As early as 1993, the Unirule Research Institute of Economics started publishing volumes of case-studies edited by economist Zhang Shuguang and his collaborators in institutional innovation in the field of law and economics. When the first volume was published in 1996, all authors

\footnotetext{
(F'note continued)

com/sol3/cf_dev/AbsByAuth.cfm?per_id=2045029 (accessed 14 July 2017) and Professor Xi Chao: https://papers. ssrn.com/sol3/cf_dev/AbsByAuth.cfm?per_id=545652 (accessed 14 July 2017).

24. Tang \& Sheng (2006); Tang \& Sheng (2009).

25. Friedman (1966).

26. One case is a critique by Professor Ai Jiahui of the work of Professor Ran Jingfu on the latter's interpretation of the historical evolution of civil litigation rates; see Ai, supra note 8.

27. Zhang (2005).

28. Rich resources regarding case-studies by Ronald Coase are available on the official website of the Coase Institute, http://www.coase.org/coasepublications.htm (accessed 14 July 2017), including a study of General Motors and one on the regulation of the Federal Communication Commission. See Cheung (2000).

29. Ellickson (1994), Chinese translation by $\mathrm{Su}$ (2003).

30. Bernstein (1992), pp. 115-57.
} 
were economists. Legal scholars began making contributions to this series when the third volume was published in 2004, on the interaction between formal and informal legal institutions. ${ }^{31}$ Another important milestone in the field is the annual Forum of Law and Economics in China, first started by two economists: Huang Shaoyan and Shi Jinchuan. In this forum, interesting and provocative case-studies as well as a quantitative study of law and economics were presented. A case-study of land reform in Chengdu, Sichuan, conducted by a team led by economist Zhou Qiren, nicely applied law and economics theories of property to China's rural land system. ${ }^{32}$

The fact economists took the lead in law and economics can be explained in terms of the nature of China's legal institutions. Formal legal rules have often been either absent or unenforced, leaving space open for informal arrangements and modified enforcement by local governments. Such modified arrangements have sometimes been illegal ${ }^{33}$ or departed $^{2}$ from the law, persisting for relatively long periods of time. ${ }^{34}$ At other times, such informal arrangements have evolved and developed into formal legal systems. ${ }^{35}$ Since Chinese legal research and education were dominated by interpretations of legislation and formal rules, legal scholars did not necessarily see a need to include informal arrangements and illegal activities in their research agendas. Moreover, when law and economic introduction was performed by jurisprudence scholars as an abstract research method, it was a bit detached from the vivid examples and legal dilemmas in the real world.

Precisely because China is a jurisdiction in the process of developing formal legal systems, it has provided legal scholars with an array of materials on which to conduct research, where alternative transactions arrangements have arisen spontaneously, which either violated the law or filled a gap left by the law in China. A number of innovative and interesting legal studies have emerged as case-studies, applying the analytical framework and methodologies of law and economics. These include papers applying game theory to interpret China's legal rules on witness, ${ }^{36}$ the research of Chinese lawyers under the framework of institutional economics and a quantitative study of legal fees, ${ }^{37}$ a series of case-studies on water right transactions, ${ }^{38}$ and urban land reform in Shenzhen. ${ }^{39}$

Compared with quantitative studies, for case-studies the legitimacy of interpretations and scope of applications are limited. However, the power of this method in outlining institutional details and framing the complexity of background conditions to individual institutions is unparalleled. In a rapidly changing society, where changes are unprecedented, such details and comprehension are indispensable for understanding these situations and resolving tensions in such development. The comparative advantage of this method has been beautifully demonstrated in the study conducted by Hou Meng regarding China's Supreme Court. ${ }^{40}$

31. Zhang \& Ding (2002).

32. Zhou (2004).

33. Such as "housing with small title" in major Chinese cities.

34. Such as the "round-about investment" widely used by private investors in the 1990s, to circumvent foreign currency restrictions over domestic investors.

35. For example, the contract responsibility system for rural land in China was apparently inconsistent with the legal rules prohibiting such an arrangement; see Chen (1993), pp. 39-49.

36. $\mathrm{Xu}(2006)$.

37. Li (2009); Cheng (2012).

38. Shen (2006).

39. Qiao (2015), pp. 197-238.

40. Hou (2007). 
Another advantage of this methodology consists of its openness to the incorporation of information from richer varieties of sources. Unlike quantitative methodology, which requires the stringent and long-term training of research staff, most legal professionals are able to engage in case-study methodology. With a much lower threshold for research skills, judges, prosecutors, and lawyers could also contribute. Such wide participation would surely enrich the information and perspectives of legal research in a rapidly changing society full of surprises and puzzles. Excellent research on criminal procedural law has clearly been beneficial. ${ }^{41}$ Although case-studies generally face more stringent scrutiny in law review publications in the US, it remains an extremely valuable and indispensable method for Chinese legal scholars. These studies might well remain limited in their application, although they undoubtedly provide rich information necessary for further research and the formulation of new rules and policies.

\section{QUANTITATIVE LAW AND ECONOMICS RESEARCH AND CHALLENGES IN CHINA}

The boundaries between different subjects and research methodologies are not defined by theory, but by their respective functions. ${ }^{42}$ This should be kept in mind in classifying different methodologies in empirical law and economics. While the methodology associated with case-studies is helpful for understanding institutional details and background information, the methodology associated with quantitative studies is much more powerful in identifying causal relationships that may be unexpected, pointing out surprising directions for improvement. The rapid development and increasing dominance of the latter in law and economics study in the US are indicative of its attractiveness features. The same is true in China, although quantitative methodology is of unique value to Chinese academia. It is scientific in nature and highly technical, requiring well-disciplined training and application. Naturally occurring discipline for academic research-in terms of norms and ethical standards-will follow from this methodology, providing strong incentives for quality research and filtering out low-quality research. In the meantime, however, I believe Chinese scholars and policy-makers should be cautious regarding its value to policy-making and research. Caution should be exercised before making substantial investments of time and capital into highly technical methodologies and giving considerable weight to the conclusions following from this methodology for policy-making. There are two reasons. Certain challenges should be overcome first, some of which are inherited in the mythologies and some are unique to China.

Quantitative study is driven by data. The choices of research subjects and hypotheses are directly limited by the availability of data, as well as the quality and contents of the data sets. Such a limitation best exemplifies the scientific nature and objectivity of this research method. However, this could result in negative consequences to the originality of legal scholarship. Assuming that research scholars also conduct certain cost-benefit analyses in choosing research subjects and establishing research agendas, subjects with a greater availability of data might attract more research attention. However, such subjects are not

41. Chi and $\mathrm{Li}$ (2009).

42. Posner (1993b), pp. 195-210. 
necessarily more important, in terms of either theoretical inquiry or practical value. If these subjects are chosen, and empirical studies are conducted on such subjects, resources could well be wasted on unimportant issues. In addition, these circumstances could well give rise to the unjustified self-growth of the field, because scholars may want to create a network with positive externality: if more participants appear in a particular subject area, then the more important this subject area would appear, and the potential gains each participant would derive from being a part of this network would potentially increase. Such conditions could incentivize scholars to attempt to grow a network such as this once it arises. However, such self-expansionary tendencies might well be harmful to society, especially legal scholarship. It could result in waste and divert resources from highly innovative fields of study that might not appear attractive in the first place. Quantitative research is particularly well known for being expensive, and is not necessarily an affordable luxury for resource-limited law schools in China. There are numerous quantitative studies of judicial behaviour in the US, but their overall value is doubtful. ${ }^{43}$ Similarly, judicial behaviour and judicial systems also attract considerable attention among scholars employing this quantitative empirical method, ${ }^{44}$ apparently influenced by American legal scholars. In the hot area of behavioural law and economics, a few Chinese scholars, led by Li Xueyao, were pioneers in using experiments in research. ${ }^{45}$ Before others follow down this same path, an awareness that China is different from the US in many important respects is necessary, which would make this topic relatively less important. For example, the judiciary does not enjoy the same degree of independence and influence in China as in the US. Although the level of transparency of judicial decisions is rapidly increasing in China, caution is necessary, since decisions to make cases public are not necessarily random. Drawing conclusions from such samples can lead to biased and even dangerous results. Fortunately, a number of scholars in China are conducting interesting research outside of judicial decisions, such as studies of legislative costs ${ }^{46}$ and securities regulations. ${ }^{47}$

The data-driven approach could affect one's creativity in yet another way: one might not be able to explore one's true passions and interests, but would be limited by the availability of quality data. Quantitative studies could undoubtedly be extremely original: the questions one asks about a given data set and causal links one identifies could be extremely original. ${ }^{48}$ However, quantitative studies rely almost completely on the extent to which data are representative. The goal of quantitative study is to prove or disapprove a widely held hypothesis. The former is usually associated with lower error rates, but the marginal benefits are regarded as minimal. The latter is regarded as more original and tends to attract more

43. The author thanks Professor Saul Levmore and Dean Thomas Miles for sharing this particular insight, both at the University of Chicago Law School. The high concentration of empirical legal work on the Supreme Court judges and their decisions is also referred to in a piece by law and economics professor David Zaring in "the Conglomerate;" see Zaring (2009).

44. See Wen (2010).

45. Li et al. (2014), pp. 148-62.

46. Wang \& Deng (2008).

47. Ibid.; supra note 24 ; see studies by $\mathrm{Xu}$ and $\mathrm{Xi}$, respectively.

48. One of the cases is a study by Cass Sunstein and his co-authors about the voting records of each of the judges in the US appeal court with respect to their decisions of judicial review of three federal regulatory agencies between 1990 and 2004, which attempted to identify the potential influences of the judges' political backgrounds and preferences over their voting decisions. The pioneering nature and development of this research project is reflected in the Chicago Judges Project, sponsored by the University of Chicago Law School. Explanations are available in Miles \& Sunstein (2006). 
attention. It is not always easy to challenge established beliefs, and the introduction of various limitations could weaken the importance and originality of the research. Therefore, scholars face a dilemma: the more original a study, the higher potential error rates, and the more investment one has to make.

Of course, one could reduce one's dependence upon the availability of quality data. For example, a research team could collect information and code this information themselves. Survey is yet another way to collect information. The Rule of Law Index, produced by a group of scholars in Zhejiang University, has utilized a lot of data of this nature. ${ }^{49}$ However, self-compiled data could lack objectivity and representativeness. When one compiles data, on one hand, and then uses these data to support one's claims, on the other hand, potential conflicts of interests arise. The risks of moral hazards are extremely high. At the same time, whether the data set is substantial enough to be representative largely depends upon one's financial means: data collection and data analysis are expensive. The third way to compile data is through experiments. Compared with the previous two methods, this manner of compiling data leaves open the widest space for manipulation. The quality of research, therefore, depends to a high degree on whether scholars maintain the highest degrees of integrity and professional ethics. Since this is difficult to ensure, experiment-oriented data and associated research should be stringently scrutinized. ${ }^{50}$

With respect to both positive and normative claims, the error rates in quantitative study are high, ${ }^{51}$ and hence require a high level of precaution and efforts. One example illustrating such risks and safeguarding efforts is legal scholarship on citations carried out by Chinese scholars, following in the footsteps of American scholars. The work by Professor Hou Meng, one of the central figures in promoting interdisciplinary legal studies in China, is one such pioneering scholarship. ${ }^{52}$ Costs and expenses of the research hence have been escalating to control such high risks. One way to appreciate the increased costs in the US is to look at the background of faculty members hired by top law schools to conduct research of this type: they have evolved from amateurs with the abilities to understand and run regression analyses to a whole new generation of scholars who have both JD and $\mathrm{PhD}$ degrees in social sciences, mainly in economics and political science.

To be sure, the development of technology, such as those for big data and Internet technologies, has dramatically reduced the high costs associated with quantitative studies. The popularity of interdisciplinary co-authorship among American scholars with different backgrounds and training has proved an effective solution, striking a better balance between high costs and controlling for the risks of error. A similar trend may develop among Chinese scholars in the future. However, the specific calculations of such cost-benefit analyses do not have to be the same in China as in the US. Chinese scholars do not have to follow the same standards and norms, in terms of publishing empirical work. Having said that, the importance and unique value that quantitative studies can provide in assessing the actual results of the implementations of laws and public policies should not be denigrated, especially given that the empirical foundations of most legislation and rule-making decisions in China are still lacking.

\footnotetext{
49. Qian et al. (2012).

50. For example, He (2010).

51. Lindgren (2006), pp. 1447-60.

52. Hou (2008).
} 
Striking such a balance requires that authors be fully aware of the potential trade-offs between the costs of research and rates of errors. Scholars should inform the audience as to how the data set has been compiled, limitations the project faces-in terms of the verification processes and applications of the conclusions drawn from particular research projects-and the need to identify the potential defects and blind spots in the research, even proposing alternative interpretations and outlining their impact on policy choices. To some extent, scholars engaging in quantitative studies need to be more conscious of the limitations and potential problems in their conclusions-more so than with other scholars. Precisely because the empirical study of law and economics appears more objective and rational, audiences might be less alert to potentially misleading and mistaken statements made in such works. When the conclusions could have profound implications for law-making and policy choices, the above-described "disclosure obligations" should be particularly emphasized. Such an obligation highlights a major difference between law and economics scholars and other social scientists, especially political scientists and sociologists in China. Legal scholars are semi-professionals, and legal scholarship often has a direct impact on individual cases and rule-making, while the impact of other social sciences scholarship tends to be indirect. Law and economics scholars owe a special obligation to the public to ensure the quality of their scholarship. ${ }^{53}$ Being candid and transparent is not a step back or defence against problems, but a necessary requirement to maintain the quality and integrity of empirical law and economics scholarship.

At the same time, one should appreciate the fact that the gap between data sets and conclusions could point towards valuable directions for future research. In quality articles of quantitative law and economics, scholars usually devote a special section to potential concerns about the data set, and potential challenges to the research and conclusions. ${ }^{54}$ In response, they sometimes try to explain why the conclusions would still hold. On other occasions, they try to point out alternative interpretations and potential directions for future research, which could either mitigate or resolve these problems. In sum, scholars are forthright about potential limitations and problems, remaining transparent and honest, without curtailing their unique contributions to the scholarship. Such standard disclosure is a critical disciplinary mechanism to ensure professional integrity, and it is one of the key considerations for editors in top journals, such as the Journal of Legal Studies. ${ }^{55}$ With more and more Chinese scholars publishing in top journals of this type, we should expect more progress from Chinese scholars in this field.

Another disclosure obligation of scholars in empirical law and economics is that of making original data available to the public for verification. Such a practice not only helps to ensure the quality of scholarship, but also helps scholars to develop their analytical skills at the same time. Length limits imposed by Chinese legal journals are relatively low, which might potentially reduce the abilities of Chinese legal authors to provide details about and

53. The author thanks Richard Epstein and Thomas Miles for sharing their insights regarding expert, originating from empirical law and economics research and provided for legislation, regulations, and judicial decisions.

54. See e.g. a paper co-authored by two law and economics scholars: Section IV(B) in Miles \& Sunstein, supra note 48 , p. 868 .

55. With respect to the influence of race and income levels on tort damages, see Helland \& Tabarrok (2003). The authors identify various problems they faced in terms of their conclusions, as well as pointing towards questions for future research. For detailed explanations of this point, the author thanks Dean Thomas Miles and Eric Posner, who were then editors of the Journal of Legal Studies. 
fully explain original data. However, given the availability of the Internet and other affordable technologies, the fulfilment of this disclosure obligations should not impose too high a burden on Chinese scholars. Hence, Chinese legal scholars should take full advantage of technologies to carefully maintain the legitimacy and reputation of research in empirical law and economics.

The second challenge facing quantitative law and economics comes from outside the legal scholarship community, specifically the quality of data and other forms of information. First-hand information and data are surely ideal. However, the relative scarcity of such information and the high costs of collecting it have forced most scholars to rely on secondhand information. Information disclosure by governments to their publics constitutes a critical source of data for social scientific research in the US. However, such sources are largely limited in China, and this constitutes a major challenge to social scientists interested in conducting quantitative work. As mentioned above, the judicial decisions and factors affecting judicial decisions have been sources of study for quantitative law and economics. However, since many judicial decisions are not made available to the public in China, it is extremely hard for legal scholars to conduct effective research and provide sensible conclusions regarding judicial decisions in China, especially those triggering public controversies. ${ }^{56}$ When basic information is lacking, scholars simply have no way to put their skills and talents to use. Fortunately, such tensions are being ameliorated following the mandate by the Chinese Supreme Court ${ }^{57}$ to establish three information platforms for the trial process, judicial decisions, and enforcement information, and the online information on these three platforms. ${ }^{58}$

Another factor contributing to this issue is that China lacks non-governmental organizations (NGOs) that could compile and provide quality information to social sciences research. The Chinese government has imposed various policy and legal restrictions on the establishment of NGOs, even though it is legally possible to establish NGOs in China. ${ }^{59}$ For-profit organizations specializing in data collection have emerged only recently and are still in their infancy. ${ }^{60}$ Information transparency of the Chinese government was addressed and accelerated when China joined the World Trade Organization (WTO). This resulted in the promulgation of China's first set of regulations regarding governmental information disclosures in 2007. Major governmental departments and local governments also issued implementation rules to enforce this set of rules. ${ }^{61}$ In April 2008, the central government's

56. Guo (2009).

57. The Supreme Court Mandate on Establishing Three Information Platforms to Promote Judicial Transparency, 2013 (最高人民法院关于推进司法公开三大平台建设的若干意见法发〔2013〕13 号).

58. The official website for video clips of court trials is http://tingshen.court.gov.cn/ (accessed 14 July 2017); the official website for judicial decisions is http://www.chinacourt.org/article/subjectdetail/id/MzAwNEiqNIABAA\%3D\% 3D.shtml (accessed 1 June 2017); and the official website for enforcement information is http://zhixing.court.gov.cn/ search/ (accessed 1 June 2017).

59. $\mathrm{Li}(2011)$, p. 2.

60. A legal database provider (Beida Fa Bao, 北大法宝) has long been providing information about judicial decisions for premier access for a fee: http://www.pkulaw.cn/Case (accessed 14 July 2017). In the US, other than information compiled and disclosed by the government and non-for-profit organizations, for-profit organizations also provide data for research, such as the Knowledge Panel, which has been used by legal scholars for research in criminal law, among others: http://www.knowledgenetworks.com/ganp/ (accessed 14 July 2017).

61. For example, the Ministry of Environmental Protection of China issued the Measures on Environmental Information Disclosure for Enterprises and Other Institutions (企业事业单位环境信息公开办法) effective as of 1 January 2015. 
information platform went online. Meanwhile, the Supreme Court of China also issued a series of rules to mandate disclosures of judicial decisions. ${ }^{62}$ There is still a long way to go in making governmental information more transparent, ${ }^{63}$ but these sources have definitely provided more information for research.

Attention should also be given to the quality of official data released by the government. One extreme example is the alleged manipulation of critical information. ${ }^{64}$ Another example supporting such a concern is the often substantial differences between official data and data provided by NGOs on the same issue. For example, information on the level of the air pollutant $\mathrm{PM}_{2.5}$ in the air of Beijing seems dramatically different, depending on the source of the information, specifically that of the Beijing Environmental Protection Bureau or the American Embassy. On certain days, the air was reported as only lightly polluted by the former but "dangerous" by the latter. ${ }^{65}$ Such a difference is puzzling, even if we take into account the possibility that the two institutions applied different standards in measuring the air quality.

In response, Chinese scholars have taken various measures to improve the quality of information that their study uses, one example of which is obtaining first-hand data directly from the government. By collecting and compiling the data themselves, scholars might have a better understanding of the data and, hence, reduce errors arising from this stage of data collection. However, such a hands-on approach could create moral hazards, given that the scholars who are trying to interpret the data are also those who collect and compile the data. So far, we do not know of any incidents where such conflicts actually arise, but such a possibility cannot be easily ruled out. For example, once a scholar obtains data on judicial decisions from a lower court, he might feel reluctant to criticize decisions made in this court or propose reform that could weaken the authorities of such a court or lower courts in general.

Having said that, I do not believe Chinese law and economics scholars should cease conducting empirical studies because of the above challenges exogenous to scholars and their studies. Furthermore, legal scholars apply empirical tools differently from social scientists such as economists and political scientists: "legal study is still largely rule-based, positive and normative," ${ }^{, 66}$ hence it does not have to rely heavily on empirical study. Meanwhile, when courts and governments make legal decisions, they face a higher degree of uncertainty, resulting from limitations in information, time, resources, and skills. ${ }^{67}$ Therefore, the inherent uncertainties in law and economics empirical studies are especially intensified in the case of China as a transitional society. Therefore, the unique value of empirical legal study lies not in the value of the highly technical tools it employs, but in the discipline it imposes on scholars to pay attention to the real world and be original without having to sacrifice transparency in the research process.

62. In the past few years, the Supreme Court has issued various rules to improve judicial transparency, such as the one in 2009 on Six Rules on Judicial Transparency (《关于司法公开的六项规定》) and Measures on Media Checks on Court (《关于人民法院接受新闻媒体與论监督的若干规定》). For the most recent summary of the status of judicial transparency in China, see the White Paper on China's Judicial Transparency (中国法院的司法公开》(白皮书)), issued by the Supreme Court of China on 10 March 2015.

63. Wang (2010b).

64. See e.g. Wang (2010a).

65. Wang (2011).

66. See challenges launched by two Harvard Law School professors: Goldsmith \& Vermeule (2002), p. 155.

67. Ibid., p. 154 . 


\section{EMPIRICAL LAW AND ECONOMICS, AND GLOBALIZATION OF CHINA'S LAW AND ECONOMICS SCHOLARSHIP}

Some followers of Professor $\mathrm{Su} \mathrm{Li}$ in the field of empirically spirited legal study in China emphasize the importance of exploring local subjects for legal study and paying attention to what has happened in real life. ${ }^{68}$ Such claims are wise, since the subjects of legal research tend to be local in nature, even though arguments and theories developed in legal research can be universal and of general application. Having said that, the effectiveness and legitimacy of certain legal claims with respect to factual evidence, either about so-called "legal facts" or legal rules, is rooted in local institutional set-ups, their cultures and customs. Hence, exploring local information and subjects is exactly the type of work in which legal scholars should engage. The interpretative power of law and economics has led to its success in both the legal sphere and policy-making, especially in the US, even though the efficacy of economics in predicting the financial crisis and addressing massive economic inequalities have been objects of attack, calling into question the value of the discipline. ${ }^{69}$ Such scholarship focuses on real issues in the day-to-day operations of legal institutions and has guided change in legislation, judicial decisions, and executive regulations, which profoundly affect legal development. Scholars have also sought to discover and draw inspiration from universal rather than merely local issues. Through such discoveries and their resulting intellectual discourse, scholars could help enhance understandings by outsiders of local issues in China, as well as those of a universal nature, thereby contributing to intellectual discourse in the global arena.

This point is particularly relevant to China's legal scholarship. Throughout the last century, jurisprudence and legal research methodologies have been introduced into China from the outside, especially those pertaining to law and economics. Such theoretical frameworks and methodologies have been derived from and developed in terms of research regarding legal issues from the West. Therefore, it is inevitable that early work in empirical law and economics studies in China have largely applied these existing frameworks and methodologies to interpret their observations in China. Producing original work is, therefore, challenging. Together with language constraints, only a small number of legal scholars are carrying out in-depth discussions with peers in the US. Empirical law and economics research provides a perfect opportunity for Chinese scholars to have breakthroughs and more actively engage in the global dialogue of legal research.

The scientific and universal nature of the research tools and methodologies applied in empirical law and economics research has made it feasible for Chinese scholars to begin this global engagement. When scholarship applies various theoretical frameworks in legal research, no substantial differences exist in the frameworks applied, such as microeconomics, ecometrics, new institutional economics, information economics, industrial organizations, game theories, etc. In this respect, the achievements made by Chinese economists in global academic research and policy-making have been extremely promising.

For approximately the past two decades, both the literature and research methods for economics in China have developed dramatically and are not substantially different from

68. Su (1996).

69. For example, see Eonomist.com (2014). 
those applied in other countries. With the aid of these universal analytical frameworks and tools, Chinese economists are able to tell stories about China in universal languages, thereby attracting global audiences among both scholars and policy-makers. Legal scholars undoubtedly face greater challenges than economists, given that legal research is of a more local nature. But law and economics-especially empirical law and economics research methods - have provided the best opportunities for overcoming these challenges thus far. For example, following the appointment of Israeli scholar Lucian A. Bebchuk as assistant professor in Harvard Law School in 1985, almost all elite American law schools have law and economics faculty members who originally came from outside the US. ${ }^{70}$ Another example is Ariel Porat, the ex-dean of Tel Aviv University Law School, who became a board member of the American Law and Economics Association and published numerous law review articles in law and economics. He also founded the journal of Theoretical Inquiries in Law, which is widely regarded as the best law and economics journal outside the US.

At the same time, foreign legal institutions provide a fresh, rich reservoir for empirical legal studies in the US and have become the subjects of top-rate legal scholarship. Some examples are the study of Japanese legal institutions conducted by Mark J. Ramseyer of Harvard Law School ${ }^{71}$ and scholarship on property in New Guinea conducted by Robert Cooter. ${ }^{72}$ The sudden collapse of the Soviet Union and fundamental transformations of previous soviet-bloc and Eastern European countries also presented opportunities for worldclass scholars in law and economics, such as Andrei Shleifer and Robert W. Vishny. The economic and social transformations in China over the past four decades are unprecedented, completely different from those in previous soviet-bloc and Latin American countries. Such novelty provides rich sources of new issues and legal scholarship. To apply universal methodologies to study these novel issues should pave a path for Chinese legal scholars to participate and take leadership roles in the global stage. Again, a generation of Chinese economists trained in top American economic schools conducted a series of studies about China's economic transitions, which proved a great success in the global stage and modernized education and research in economics in China, such as those by Professor Xu Chenggang, the Director of the Law and Economics Institute in KoGuan Law School of Shanghai Jiao Tong University. ${ }^{73}$ Other legal scholars, two legal sociologists (Professor Ji Weidong and Professor Liu Sida), and two law and economics scholars (Qiao Shitong and Liu Zhuang) received tenure positions in top universities outside of China, ${ }^{74}$ evidencing again the feasibility of this developmental path.

Another possible approach to more fully participating in the mainstream of law and economics studies is for Chinese legal scholars to apply universal analytical tools to target

70. Such as Oren Bar-Gill at New York University Law School and Omri Ben-Shahar at the University of Chicago Law School.

71. See the works of Ramseyer (2003, 2009, 2012).

72. Cooter (1991), pp. 759-801.

73. The high point in the achievements of these Chinese economists is Dr Justice Lin's appointment as Chief Economist of the World Bank.

74. Professor Ji Weidong is now the Dean of the KoGuan Law School of Shanghai Jiao Tong University. He was appointed to a tenured position in Japan in 1990 and was later promoted to a full professorship in 1996. Liu Sida received a tenure-track appointment in the University of Wisconsin-Madison in 2009 and in the University of Toronto in 2016. Qiao Shitong and Liu Zhuang are assistant professors at Hong Kong University and the Chinese University of Hong Kong, respectively. 
purely domestic issues in the US. Taiwanese property law scholar Yun-Chien Chang is an example: his quantitative study of compensation level in eminent domain in New York has initiated major discussions among property scholars in the US. ${ }^{75}$ Such an approach is, of course, more straightforward, but also much more difficult, given the relatively high threshold to participate, in terms of background knowledge of the legal and institutional arrangements and ability to engage local audiences. A middle path more feasible for Chinese scholars would be co-authorship with top law and economics scholars in the relevant fields.

\section{CONCLUSIONS}

More than ten years ago, "an extraordinary coincidence" (as described by Ronald Coase) occurred in American law and economics scholarship: the Journal of Legal Studies published three articles in one issue, all targeting a classical piece in the area of industrial organizations, which had drawn numerous followers and verification later on. ${ }^{76}$ All three articles are based on fieldwork and interviews conducted by the respective authors, and all challenged the facts on which the original piece was based, as either false or unrealistic. During the same year, two other top economics journals published other articles similarly supporting the above challenges. What makes the whole event truly striking is that all five papers and associated projects were conducted independently without knowledge of the others. ${ }^{77}$ This case remains unsettled, but it powerfully demonstrates the importance of empirical work. Ronald Coase also emphasized that debates in this case require scholars to empirically verify theoretical claims. This story is relevant to Chinese legal scholarship as well. To reinstate the empirical nature of law and economics is particularly timely: law and economics has always been empirical, and it is impossible to imagine law and economics scholarship that is not essentially empirical. However, when it was first introduced into China's legal academy, law and economics was described as a new school of Western ${ }^{78}$ thought instead of a research methodology focusing on the consequences of the operations of legal rules in the real world. Twenty years later, providing a review of empirical law and economics studies in China, I hope to draw attention to empirical studies and provide a roadmap for future research.

This road map is not meant to constrain creativity in scholarship by excluding less common avenues of study, nor to induce divisions or carve out fiercely territories domains of research specialization. On the contrary, diversity in the individual choices of scholars-in terms of research agendas and methodologies—should be respected. In response to rapid developments within case-studies and the bourgeoning field of quantitative research among legal scholars, encouragement and support should be given, since the lifeblood of academic pursuits lies in unpredictability and surprise. The choices of scholars and development of

75. Chang (2010), pp. 201-44.

76. Klein et al. (1978), pp. 297-326.

77. See Coase (2006), pp. 255-78. The debate is about the acquisition of Fisher Body by General Motors. In 1978, a paper used this transaction as an example to illustrate the point that vertical integration was applied to reduce problems caused by the specialization of human and physical capital. Since then, this case has become one of the most cited. See Freeland (2000), p. 34. For the response from the original author and other following papers, see ibid.; Klein (1991); Klein (1992).

78. Zhou \& Sun (2008). 
methodologies are perfect examples of "spontaneous order." Moreover, this order is not limited by national boundaries. Empirical law and economics research provides a feasible path for Chinese scholars to develop genuinely global perspectives and participate in academic discourses at a truly global level.

Meanwhile, scholars should be fully alert to the limitations and disadvantages of various research methodologies, thereby upholding a high standard of professional ethics. Such standards could, in turn, provide a healthy environment and set of rules for debates and criticisms among scholars. In particular, empirical law and economics scholars should be careful to maintain transparency in the collection and analysis of data, and integrity in their broader research agendas. Moreover, empirical study is open to all: no one can monopolize the research of a particular topic, since the research subjects are live individuals with behaviours occurring in the real world. Similarly, one's research is always open and subject to independent verification by other scholars. Therefore, scholars in the field should consider these conditions an integral part of their research, allowing others to verify their results by making data available and providing assistance necessary for the verification of results. In being challenged or receiving criticisms, one should not take it personally.

We are extremely lucky to live at a time when the world has never been as open and integrated as it is now. Pursuing legal education and research, scholars should be confident in confronting challenges from increasing globalization and quick to adapt. Passion for identifying and dealing with local issues should not blind one's attention to the rest of the world, since China is certainly an increasingly critical part of that world. Stating that the future will be determined, to a large extent, by the future of China is not an exaggeration. Climate change is an important example of this dynamic, ${ }^{79}$ which has emerged as one of the highest priorities for policy-making in the global sphere. China plays a critical role in shaping rules and legal institutions to deal with climate change. So critical is China's active participation that any global climate change regime without its co-operation could simply fail to work. All human beings should benefit from quality academic scholarship. Therefore, China is obliged to share with the rest of the world observations of its unprecedented challenges and experiences, although hurdles regarding language and background knowledge require Chinese scholarship to be extremely diligent and persistent. Empirical legal study may well act as a Silk Road between China and the rest of the world.

\section{REFERENCES}

$\mathrm{Ai}$, Jiahui (2007) “民事诉讼率变迁的背后一评苒井富 当代中国民事诉讼率变迁研究” [“Behind the Evaluation of Civil Litigation Rates: A Comment on the Research of the Evolution of Civil Litigation Rates in Contemporary China by Ran, Jingfu"]. 2 司法 [The Judiciary] 308-17.

Bai, Jianjun (2000) “论法律实证分析” [“On Empirical Legal Study”]. 4 中国法学 [China Legal Science] 29-39.

Bai, Jianjun (2001) “刑罚轻重的量化分析” [“Quantitative Analysis of Sentencing in Criminal Cases”]. 6 中国社会科学 [China Social Science] 114-25.

Bai, Jianjun (2003) “犯罪轻重的量化分析” [“Quantitative Analysis of Crimes”]. 6 中国社会科学 [China Social Science] 123-33.

Bai, Jianjun (2008) 法律实证研究方法 [Empirical Legal Research Methodologies], Beijing: Peking University Press.

79. Stern (2017). 
Bar-Gill, Oren, \& Richard A. Epstein (2007) "Consumer Contracts: Behavioral Economics vs. Neoclassical Economics." NYU Law and Economics Research Paper No. 07-17. 92 Minnesota Law Review.

Becker, Gary (1968) "Crime and Punishment: An Economic Approach." 76 Journal of Political Economy 169-217.

Bernstein, Lisa (1992) "Opting Out of the Legal System: Extralegal Contractual Relations in the Diamond Industry." 21 Journal of Legal Studies 115-57.

Chang, Yun-Chien (2010) "An Empirical Study of Compensation Paid in Eminent Domain Settlements: New York City, 1990-2002.” 39 Journal of Legal Studies 201-44.

Chen, Xiwen (1993) 中国农村改革 : 回顾与展望 [China's Rural Reform: Reflections and Prospect], Tianjin: Tianjin People's Press.

Cheng, Jinhua (2012) “中国律师择业理性分析一以业务收费为核心的实证研究” [“Rational Analysis of the Career Choices of Chinese Lawyers: An Empirical Study on the Legal Fees"]. 11 法 学 [Legal Studies] 143-55.

Cheng, Jinhua (2015) “当代中国法律实证研究” [“Empirical Legal Studies in Contemporary China”]. 6 中国法学 [China Legal Studies] 60-78.

Cheung, Steven (2000) 佃农理论一一佃农理论：应用于亚洲的农业和台湾的土地改革 [The Theory of Share Tenancy: with Special Application to Asian Agriculture and the First Phase of Taiwan Land Reform], Beijing: Shangwu Press.

Chi, Xiaojuan, \& Fang Li (2009) “存疑不起诉的证据问题之实证研究” ["Empirical Study of Issues of Evidence in the Decision of None Prosecution"]. 6 法律评论 [Legal Commentary] 102-10.

Coase, Ronald (1994a) "George J. Stigler," in R. Coase, ed., Essays on Economics and Economists, Chicago: University of Chicago Press, 199-207.

Coase, Ronald (1994b) "The Institutional Structure of Production," in R. Coase, ed., Essays on Economics and Economists, Chicago: University of Chicago Press, 3-14.

Coase, Ronald (2006) "The Conduct of Economics: The Example of Fisher Body and General Motors." 15 Journal of Economics \& Management Strategies 255-78.

Cooter, Robert (1991) "Inventing Market Property: The Land Courts of Papua New Guinea." 25 Law \& Society Review 759-801.

Demsetz, Harold (1993) "George J. Stigler: Midcentury Neoclassicist with a Passion to Quantify." 101 Journal of Political Economy 793-808.

Ding, Li (2005) “核实技术、激励与举证责任配置” [“Verification Technology, Incentives and the Allocation of Burden of Proof']. 4 中外法学 [Peking University Law Journal] 479-87.

Economist.com (2014) "Economic Models and Financial Crises: Why They Crashed Too," http:// www.economist.com/blogs/freeexchange/2014/06/economic-models-and-financial-crisis (accessed 28 May 2017).

Ellickson, Robert (1994) Order without Law: How Neighbors Settle Disputes, Cambridge: Harvard University Press.

Epstein, Lee, \& Gary King (2002) "The Rules of Inference." 69 University of Chicago Law Review $1-133$.

Feng, Yujun (2006) 中国法经济学应用研究 [Application Research of Law \& Economics in China], Beijing: Law Press.

Freeland, Robert (2000) "Creating Holdup Problem through Vertical Integration: Fisher Body Revisited." 43 Journal of Law \& Economics 33-66.

Friedman, Milton (1966) "The Methodology of Positive Economics," in M. Friedman, ed., Essays in Positive Economics, Chicago: University of Chicago Press, 3-16.

Goldsmith, Jack, \& Adrian Vermeule (2002) "Empirical Methodology and Legal Scholarship." 69 University of Chicago Law Review 153-67.

Guo, Yunzhong (2009) “法律实证研究方法研讨会综述” [“Proceedings of the Conference on Legal Empirical Study”]. 4 国家检察官学院学报 [National Prosecutors Institute Journal] $140-7$.

He, Ting (2010) “法律实证研究中的实验方法” [“Experiments in Legal Empirical Study”]. 2 国家检 察官学院学报 [National Prosecutors Institute Journal $]$ 77-83. 
Helland, Eric, \& Alexander Tabarrok (2003) "Race, Poverty, and American Tort Awards: Evidence from Three Data Sets." 32 Journal of Legal Studies 27-58.

Hong, Yongmiao (2007) “计量经济学的地位 、作用和局限” [“The Status, Function and Limitation of Economics"]. 5 经济研究 [Economic Research Journal] 1-14.

Hou, Meng (2007) 中国最高人民法院研究—以司法的影响力切入 [A Research on China's Supreme Court: From the Perspective the Judicial Influence], Beijing: Law Press.

Hou, Meng (2008) “数据如此分组能否真实反映法学现状一评《中国人文社会科学学术影响力 报告》法学部分” [“Whether the Classification of Data Could Reflect the Reality of Legal Scholarship? A Comment on the Report on the Academic Influences of China's Social Sciences"]. 3 法学 [Legal Studies] 30-8.

Huang, Tao (2014) “台湾地区法律经济学研究现状及其成因一以法学知识生产为分析框架” ["Law and Economics Scholarship and Its Roots in Taiwan: From the Perspective of the Production of Legal Knowledge"]. 1 华东政法大学学报 [Journal of the China Eastern University of Politics and Law] 136-49.

Klein, Benjamin (1991) "Vertical Integration as Organizational Ownership: The Fisher Body-General Motors Relationship Revisited," in O. Williamson \& S. Winter, eds., The Nature of the Firm: Origins, Evolution, and Development, New York: Oxford University Press, 213-26.

Klein, Benjamin (1992) "Contracts and Incentives: The Role of Contract Terms in Ensuring Performance," in L. Werin \& H. Wijkander, eds., Contract Economics, Cambridge, MA: Blackwell Publishing, 149-72.

Klein, Benjamin, Robert Crawford, \& Armen Alchian (1978) "Vertical Integration, Appropriable Rents, and the Competitive Contracting Process." 21 Journal of Law \& Economics 297-326.

Landes, William (2003) "The Empirical Side of Law \& Economics." 70 University of Chicago Law Review $167-70$.

Landes, William, \& Richard Posner (1993) "The Influence of Economics on Law: A Quantitative Study." 36 Journal of Law \& Economics 385-424.

Li, Guoqing (2009) “中国律师产业实证研究一从进入壁垒切入” [“Empirical Study of China's Lawyers as an Industry: From the Perspectives of Entry Barriers"]. 4 法律和社会科学 [Law and Social Science Journal] 37-196.

Li, Xueyao, Ge Yan, , Juntao He, \& Qinyu Lin (2014) “认知流畅度对司法的影响” [“The Impact of Processing Fluency on Judicial Decisions"]. 5 中国社会科学 [China Social Science] $148-62$.

Li, Yuwen (2011) NGOs in China and Europe: Comparisons and Contrasts, London \& New York: Routledge.

Lindgren, James (2006) "Predicting the Future of Empirical Legal Studies." 86 Boston University Law Review 1447-60.

Luo, Peixin, ed. (2006) 法律经济学译丛 [Law and Economics Translation Series], Shanghai: Fudan University Press.

Miles, Thomas, \& Cass Sunstein (2006) "Do Judges Make Regulatory Policy? An Empirical Investigation of Chevron." 73 University of Chicago Law Review 823-81.

Posner, Richard (1993a) "Gary Becker's Contributions to Law and Economics." 22 Journal of Legal Studies 211-15.

Posner, Richard (1993b) "Nobel Laureate: Ronald Coase and Methodology." 4 Journal of Economics Perspectives 195-210.

Qian, Hongdao (2003) 经济分析法学 [Economic Analysis of Law], Beijing: Law Press.

Qian, Hongdao, Ge Wang, \& Dawei Liu (2012) “法治评估及其中国应用” [“The Rule of Law Index and Its Application in China”]. 4 中国社会科学 [China Social Science] 140-60.

Qiao, Shitong (2015) "Small Property, Big Market: A Focal Point Explanation.” 63 American Journal of Comparative Law 197-238.

Ramseyer, Mark (2009) "Universal Health Insurance and the Effect of Cost Containment on Mortality Rates: Strokes and Heart Attacks in Japan.” 6 Journal of Empirical Legal Studies 309-42.

Ramseyer, Mark (2012) "Talent Matters: Judicial Productivity and Speed in Japan.” 32 International Review of Law and Economics 38-48. 
Ramseyer, Mark, \& Eric Rasmussen (2003) Measuring Judicial Independence: The Political Economy of Judging in Japan, Chicago: University of Chicago Press.

Shen, Manhong (2006) 水权交易制度研究一中国的案例分析 [A Research on Water Transactions: Case Study in China], Hangzhou: Zhejiang University Press.

Shi, Jinchuan, ed., 法律经济学博士文丛 [Law and Economics PhD Thesis Series], Hangzhou: Zhejiang University Press.

Shi, Jinchuan (2014) 法经济学 [Law \& Economics], Beijing: Peking University Press.

Stern, Nicholas (2017) "China Is Shaping to Be a Leader in Climate Change: Xi Jinping's Davos Speech Showed Promising Signs," Financial Times, 20 January.

Stigler, George (1971) "The Theory of Economic Regulation." 2 Bell Journal of Economics \& Management Science 3-21.

Stigler, George, \& Claire Friedland (1962) "What Can Regulators Regulate? The Case of Electricity." 5 Journal of Law \& Economics 1-16.

$\mathrm{Su}, \mathrm{Li}$ (1996) 法治及其本土资源 [Rule of Law and Local Resources], Beijing: China University of Politics and Law.

$\mathrm{Su}, \mathrm{Li}$ (2003) Chinese translation. Beijing: China University of Politics and Law Press (苏力 (译) 《无需法律的秩序一一邻人如何解决纠纷》, 中国政法大学出版社, 北京, 2003年).

$\mathrm{Su}, \mathrm{Li}$ (2006a) “社会转型中的中国学术传统” [“China's Academic Traditions in the Social Transformation"]. 1 法律和社会科学 [Law \& Social Sciences] 1-7.

$\mathrm{Su}, \mathrm{Li}$ (2006b) “海瑞定理的经济学解释” [“An Economic Analysis of the Hairui Theorem”]. 6 中国 社会科学 [China Social Science] 116-32.

Sunstein, Cass (2000) Behavior Law and Economics, Cambridge, MA: Cambridge University Press.

Tang, Yingmao, \& Liugang Sheng (2006) “民商事执行程序中的“双高现象” [“The Puzzle of the 'Two Highs' in Civil Enforcement Procedures”]. 1 法律和社会科学 [Law \& Social Sciences] $1-29$.

Tang, Yingmao, \& Liugang Sheng (2009) “中国司法执行难的计量分析” [“A Statistical Analysis of the Dilemma in the Enforcement of Judicial Decisions in China”]. 4 法律和社会科学 [Law \& Social Sciences] 197-238.

Wang, Jiao, \& Zhengjun Lai (2008) “实证研究在法经济学分析中的运用现状探析” [“Current Status of Empirical Study in Law and Economics"]. 11 法制与社会 [Rule of Law and Society] 94-5.

Wang, Jin (2011) 环保法治三十年:我们成功了吗:中国环保法治蓝皮书 (1979-2010) [30 Years of Environmental Protection: Have We Succeeded? Blue Paper on China's Environmental Protection (1979-2010)], Beijing: Peking University Press.

Wang, Baoquan (2010a) “统计局官员称统计造假现象严重 GDP政绩化” [“Officials of the Statistics Bureau Claimed that Data Fraud is Serious and the GDP Performance Is Distorted"], 中国新闻周刊 [China News Weekly], 9 June.

Wang, Xixin (2010b) “北大法学教授王锡锌: 政府信息公开应上到法律层面” [“The Transparency of Government Information Shall Become an Issue for Legislation”], 中国新闻周刊 [The News Center, State Council of China], 21 May, http://www.scio.gov.cn/m/ztk/dtzt/25/15/Document/ 643419/643419.htm (accessed 28 May 2017).

Wang, Xuehui, \& Huaping Deng (2008) 行政立法成本分析和实证研究 [Cost and Benefits Analysis of Administrative Legislation and Empirical Study], Beijing: Law Press.

Wang, Ying, \& Meng Hou (2007) “法律现象的实证调查 : 方法和规范一“法律的社会科学研究”研 讨会综述” [“Empirical Study of Legal Phenomenon, Methodologies and Norms: Proceedings of the Social Science Research of Law Conference”]. 2 中国社会科学 [China Social Science] 119-37.

Wen, Lijun (2010) “司法的经济学分析 : 研究综述” [“A Survey of Law and Economics Research on Judicial Decisions"]. 1 知识经济 [Knowledge Economics] 29-40.

Wright, Joshua, \& George Stigler (2006) "The Father of Empirical Law and Economics?," Esl blog, 14 August, http://www.elsblog.org/the_empirical_legal_studi/2006/08/george_stigler_.html (accessed 28 May 2017).

Xi，Tao (2013) 法律经济学一直面中国问题的法律与经济 [Law and Economics: Confronting Law and Economy in Chinese Problems], Beijing: China University of Political Science and Law Press. 
Xu, Xin (2006) “法官为什么不相信证人? 一证人在转型中国司法过程中的作用” [“Why Judges Do Not Trust the Witnesses? The Function of Witnesses in China's Judicial Transformation"]. 3 中 外法学 [Peking University Law Journal] 337-50.

Zaring, David (2009) “Empirical Legal Studies Today,” The Conglomerate, 23 November, http://www. theconglomerate.org/2009/11/empirical-legal-studies-today.html (accessed 28 May 2017).

Zhang, Jianwei (2005) “主流范式的危机：法律经济学理论的反思与重整” [“The Crisis of the Mainstream: Reflection on and a Proposal to Reconstruct Law and Economics Theories"]. 4 法制与 社会发展 [Law and Social Development $]$ 130-52.

Zhang, Naigen (1995) 经济学分析法学一评介及其比较 [Economic Analysis of Law: Comments and Comparison], Shanghai: Shanghai Sanlian Press.

Zhang, Shuguang, \& Ding Li (2002) “前言：演进社会中的制度设计与实施” [“Forward: Institutional Design and Implementation in Rapidly Transiting Society"], in S. Zhang \& L. Ding, eds., 中国制度变迁的案例研究, 中国财政经济出版社 [Case Study of Institutional Evolution in China], Beijing: China Finance and Economic Press, 1-23.

Zhang, Weiyi, \& Feng Deng (2003) “信息、激励与连带责任一对中国古代连坐 、保甲制度的法 和经济学解释” [“Information, Incentives and Joint and Several Liabilities: An Law and Economic Analysis of Two Institutions in Ancient China”]. 3 中国社会科学 [China Social Science] 99-112.

Zhou, Linbin (1998) 法律经济学论纲 [On Law and Economics], Beijing: Peking University Press.

Zhou, Linbin (2006) “中国法律经济学的实务研究问题” ["Practical Research Topics in China's Law and Economics”]. 10 学术研究 [Academic Research] 64-70.

Zhou, Linbin (2007) “中国法律经济学研究中的定量分析问题” [“Quantitative Analysis in China's Law and Economics Research"]. 1 制度经济学研究 [Institutional Economics Research] 19-34.

Zhou, Linbin, \& Linling Sun (2008) “忽如一夜春风来-中国大陆法律经济学的发展” [“Development of Law and Economics in Mainland China”], 社会科学报 [China Social Science Newspaper], 27 November.

Zhou, Qiren (2004) “农地产权与征地制度一中国城市化面临的重大选择” [“Rural Land Property Rights and Eminent Domain: Major Choices for China's Urbanization”], in Q. Zhou, ed., 产权与制 度变迁：中国改革的经验研究 [Property and Institutional Development: Empirical Study of China's Reform], Beijing: Peking University Press, 83-121. 